\title{
Revegetation of an Airstrip and Dirt Roads in Central East Greenland
}

\author{
FRITZ HANS SCHWARZENBACH ${ }^{1}$
}

\author{
(Received 24 March 1994; accepted in revised form 20 February 1996)
}

\begin{abstract}
Revegetation of an airstrip and associated dirt roads on Pingo Pass, central East Greenland $\left(71^{\circ} 48^{\prime} \mathrm{N}, 24^{\circ} 15^{\prime} \mathrm{W}\right)$, was studied in 1991, 34 years after their construction and abandonment. Sixty-two of the 103 species occurring on the Pass were found on the study sites. This relatively fast rate of recolonization might be partially explained by the fact that the ecological conditions of the surrounding area with windswept and rather stony terraces are similar to the dry and compressed soil on the airstrip and on the dirt roads. Therefore, the species of the dry barren grounds and of the dry heath could reach the airstrip easily and start the process of recolonization as pioneer plants. For most species, two phases of colonization can be recognised: the initial establishment of pioneer individuals followed by the establishment around them of their progeny.
\end{abstract}

Key words: East Greenland, vegetation, vascular plants, revegetation, recolonization, airstrip, dirt roads

RÉSUMÉ. En 1991, on a étudié la régénération de la végétation d'une piste d'atterrissage et de deux chemins de terre connexes au col Pingo - centre du Groenland oriental ( $71^{\circ} 48^{\prime}$ de latit. N., $24^{\circ} 15^{\prime}$ de longit. O.) —, 34 ans après leur construction et leur abandon. On y a trouvé 62 des 103 espèces présentes au col. Cette reconstitution relativement rapide peut être en partie expliquée par le fait que les conditions écologiques de la région avoisinant le site (terrasses plutôt pierreuses balayées par le vent), sont semblables à celles du sol sec et comprimé de la piste d'atterrissage et des chemins de terre. Les espèces de la toundra claire et de la lande aride pouvaient donc atteindre facilement la piste et commencer le processus de reconstitution en tant que plantes pionnières. Pour la majorité des espèces, on peut distinguer deux phases de reconstitution: l'implantation initiale d'individus pionniers, puis l'établissement, dans le périmètre immédiat, de leurs descendants.

Mots clés: Groenland oriental, végétation, plantes vasculaires, régénération de la végétation, reconstitution, piste d'atterrissage, chemins de terre

Traduit pour la revue Arctic par Nésida Loyer.

\section{INTRODUCTION}

In the late 1950s, an airstrip and associated dirt roads were constructed by the Northern Mining Company on Pingo Pass in western Jameson Land, central East Greenland, $71^{\circ} 48^{\prime} \mathrm{N}, 24^{\circ} 15^{\prime} \mathrm{W}$ (Figs. 1 and 2). Their purpose was to provide a base for topographic mapping and ore prospecting. According to the available information, the airstrip has been abandoned since 1958. Later it was used once when a field party had to remove material and rubbish left behind by the prospecting group.

In 1991, a detailed investigation was made of the revegetation of the landing strip and the two associated dirt roads. Its purpose was to describe the process of recolonization since the construction of the landing strip and the roads (approximately 34 years) and to compare the present state of the plant cover with the natural vegetation outside the disturbed area.

The Pass lies at $500 \mathrm{~m}$ on the watershed between the deep Schuchert Dal catchment basin to the west, which drains the southeast Staunings Alper, and Pingo Dal, which flows eastwards into Ørsted Dal and ultimately into Fleming Fjord at Kong Oscar Fjord (Fig. 2).
The geology is described by Henriksen et al. (1980) and shown on a geological map scaled at 1:100 000. The Schuchert Dal separates the sediments found in Jameson Land and the Pingo Pass area in the east from the crystalline rocks of the southern Staunings Alper in the west. North of Pingo Pass, there are interesting contact zones with metamorphic rocks.

The Pass (Fig. 2) is bordered by a series of moraines left by the ice that spilt over from Schuchert Dal to flow down Pingo Dal, resulting in the formation of the small lake Loms $\varnothing$ just east of the crest of the pass. To the north lie the Werner Bjerge, which rise to $1680 \mathrm{~m}$, and to the south are a succession of lower summits, the Gurreholm Bjerge, formed from Mesozoic sediments and flanking the eastern side of Schuchert Dal. The permafrost conditions in the Pingo Dal east of the area have been studied by Müller (1959).

The windswept airstrip lies in a zone of sediments. The soil consists of a hard layer of fine material on a bed of stones. The airstrip is fairly well drained and dries fast after the melting of the snow. Snow accumulates in niches at the edges of the airstrip. The influence of permafrost is only slight: the surface is soaked with water for only a

${ }^{1} \mathrm{CH}-6714$ Semione, Switzerland

(C) The Arctic Institute of North America 


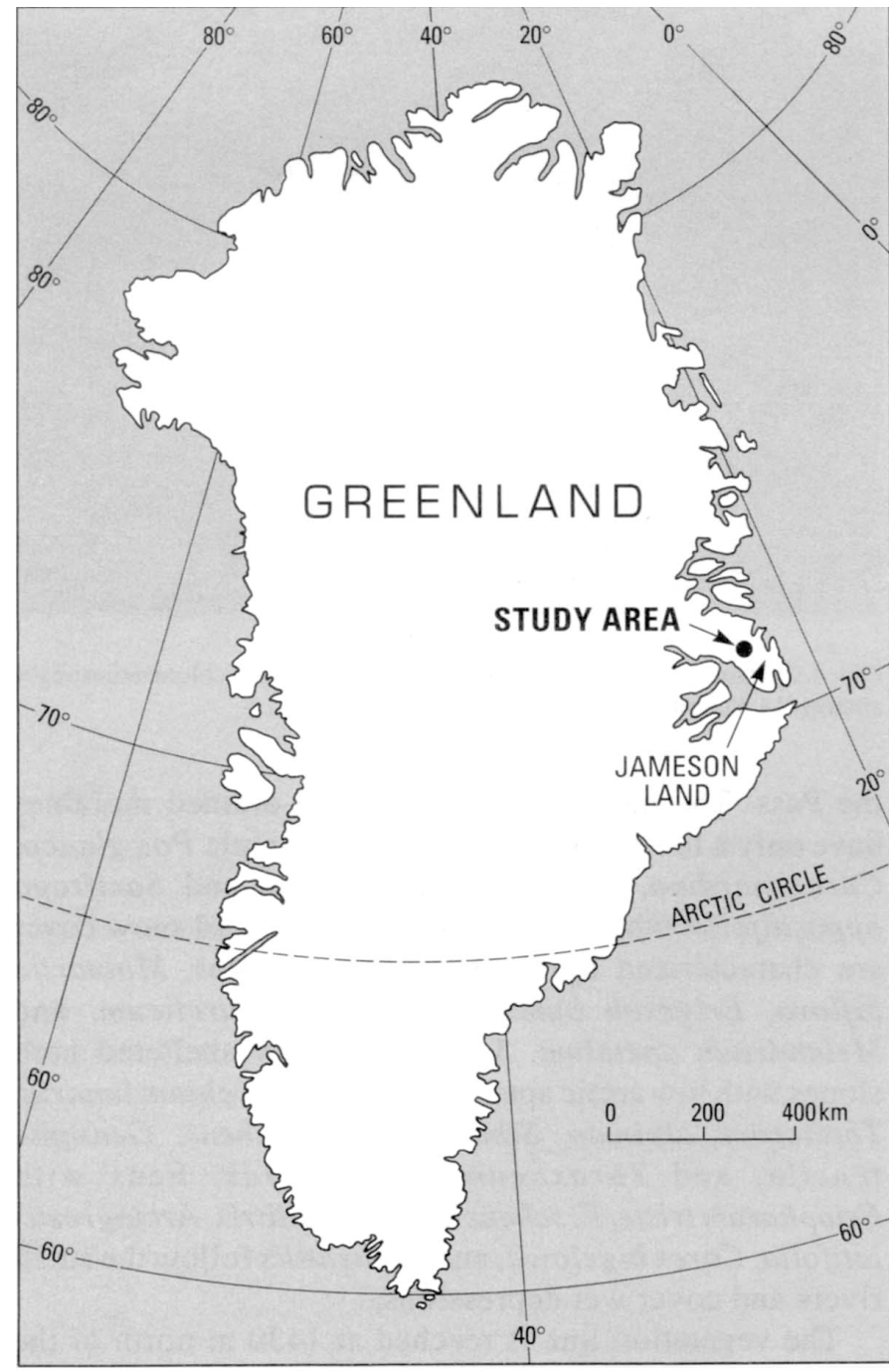

FIG. 1. Situation of the Pingo Pass area in Greenland.

short time during the melting of the snow. There are no signs of active cryoturbation. Cracks of the soil occur when the surface is drying (Figs. 3 and 4).

The climate of the area might be compared with the conditions of Jameson Land (Anonymous, 1989). The nearest station is Station 133 (established July 1982) situated $261 \mathrm{~m}$ above sea level at the position $71^{\circ} 10^{\prime} \mathrm{N}$ and $23^{\circ} 37^{\prime} \mathrm{W}$. Meteorological data have been registered automatically since 28 July 1982. Data from Station Mestersvig $\left(72^{\circ} 15^{\prime} \mathrm{N}, 23^{\circ} 54^{\prime} \mathrm{W}\right)$ are given for the period 1961-85. The mean monthly temperatures for the five months May to September are shown for both stations in Table 1. Data for monthly precipitation are published only for Station Mestersvig (1961-85). The temperatures of the Pingo Pass area seem to be approximately $1^{\circ} \mathrm{C}$ lower than those at Station 133 because of the higher altitude. Local and topographical conditions often cause the weather situation to change within hours.

Precipitation and accumulation maps published by Ohmura and Reeh (1991) show that the total annual pre-

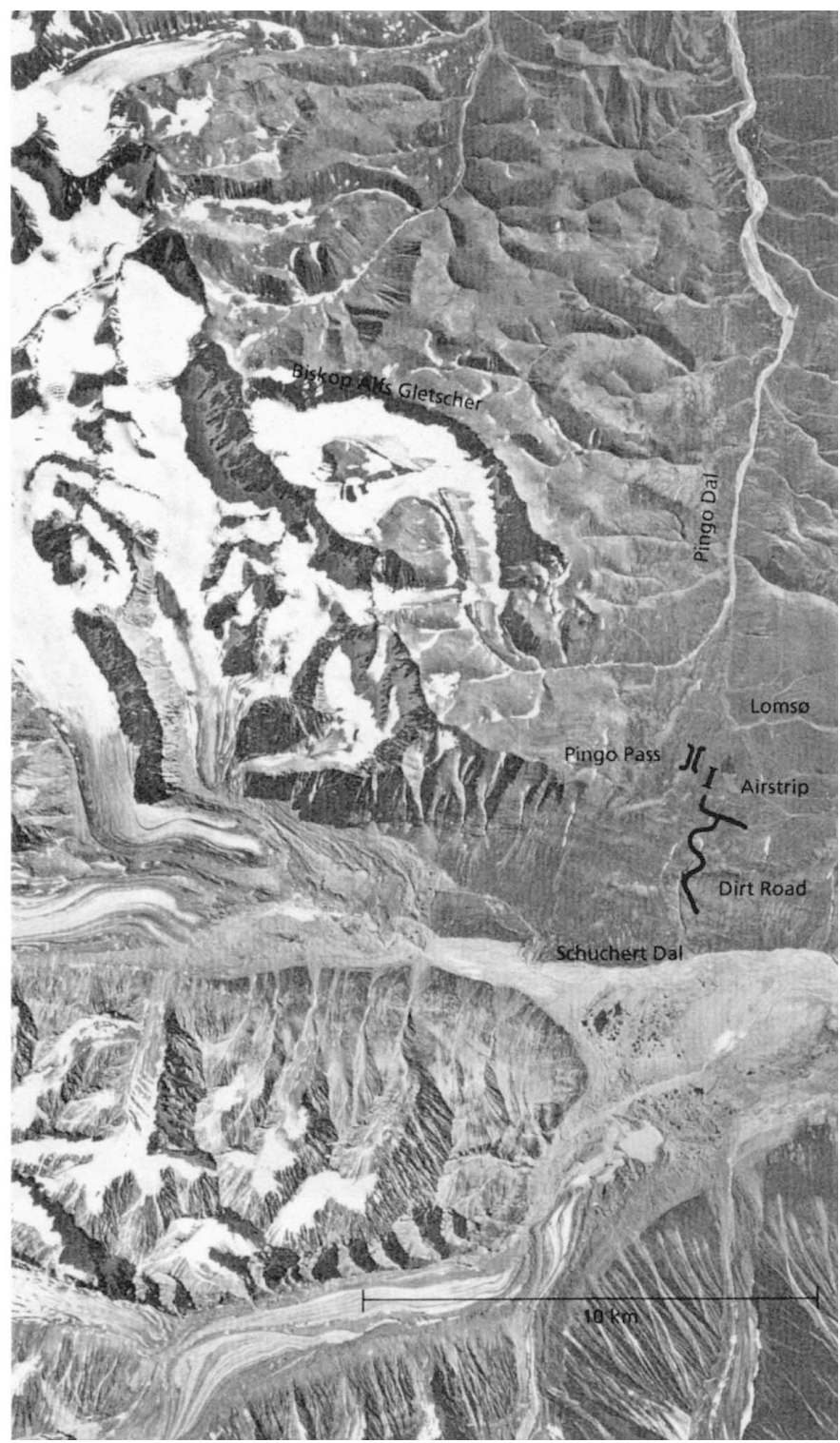

FIG. 2. Map of the Pingo Pass area based on the aerial photo 1:150 000, 7 August 1987. (FK nr. 87.716MM 888-M-11239), reproduced with permission of the Danish National Survey and Cadastre - Denmark.

cipitation in the area ranges between $300 \mathrm{~mm}$ and $400 \mathrm{~mm}$, falling mainly as snow.

\section{VEGETATION}

The vegetation of East Greenland from $70^{\circ}$ to $80^{\circ} \mathrm{N}$ is well known (e.g., Sørensen, 1933; Gelting, 1934; Seidenfaden and Sørensen, 1937; Schwarzenbach, 1960, 1961; Böcher et al., 1978; Halliday, 1981; Bay, 1992). The results of detailed studies on the vegetation of Jameson Land southeast of the Pingo Pass area have been published by Fredskild et al. (1982, 1986), Holt (1984), Bay and Holt (1986), and Fredskild (1990).

The vegetation of the Pingo Pass area has an intermediate position between the very rich and often luxuriant 


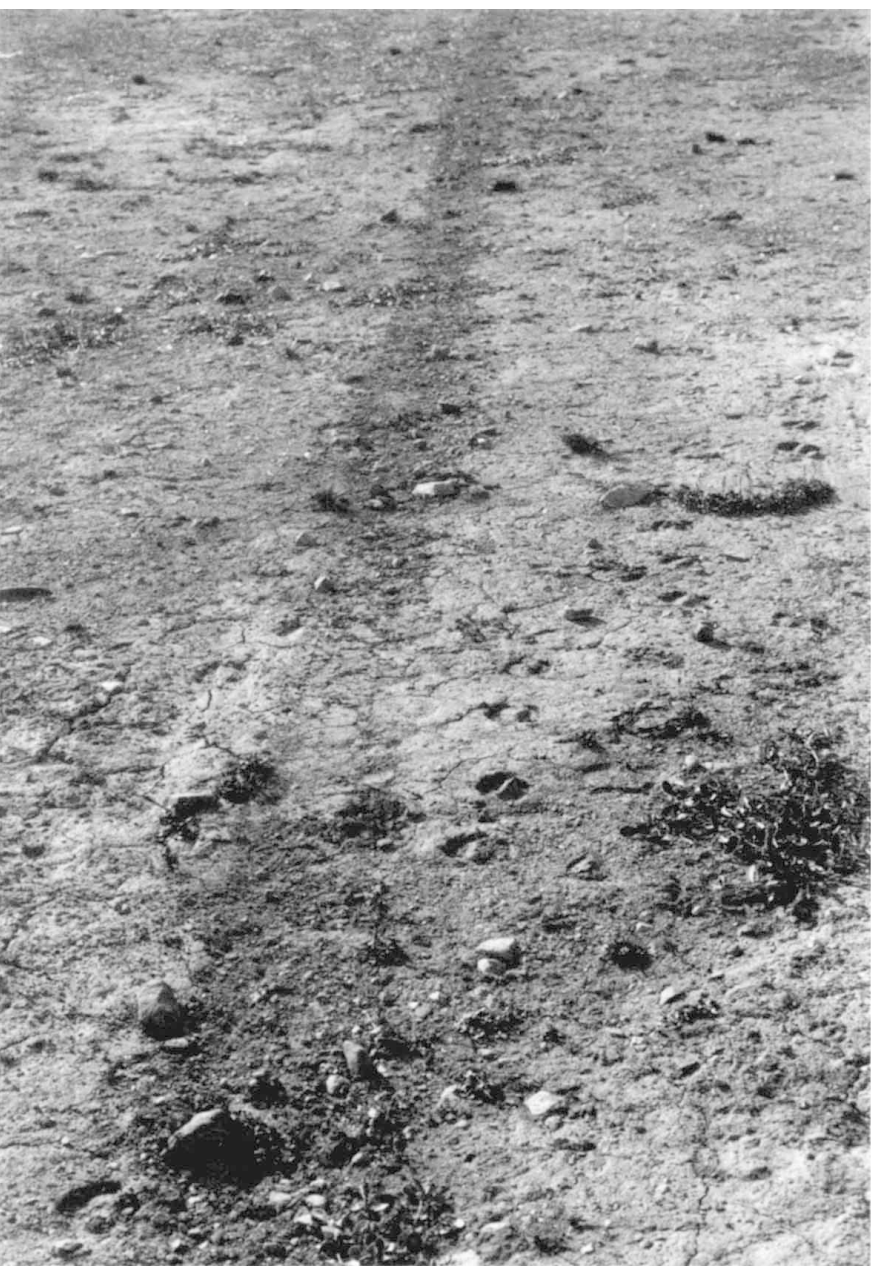

FIG. 3. Surface of the airstrip. Tracks of the Twin Otter and prints of hooves of a musk-ox show the structure and consistency of the soil (3 August 1991).

vegetation of the unglaciated area of Jameson Land, with sedimentary rocks, and the mountain vegetation of the granitic Staunings Alper, with peaks up to $2930 \mathrm{~m}$ and many glaciers of alpine type.

The list of species is similar to the plant lists published by Fredskild et al. $(1982,1986)$ for the northwestern part of Jameson Land.

The exposed and windswept plateau of Pingo Pass supports a poor and rather open vegetation, variously dominated by Cassiope tetragona, Salix arctica, Dryas octopetala or Carex rupestris and C. nardina. This is in a marked contrast to the often luxuriant Betula nana heaths on the warm, west-facing slopes of Schuchert Dal below

TABLE 1. Mean monthly temperatures and precipitation.

\begin{tabular}{lrrrrr}
\hline \hline & May & June & July & Aug. & Sept. \\
\hline Mean temp. $\left({ }^{\circ} \mathrm{C}\right)$ & & & & & \\
$\quad$ Station 133 & -1.5 & 6.2 & 9.3 & 7.6 & -0.3 \\
$\quad$ Mestersvig & -4.8 & 1.6 & 5.2 & 5.3 & -0.6 \\
$\begin{array}{l}\text { Precipitation (mm) } \\
\text { Mestersvig }\end{array}$ & 13.8 & 18.3 & 28.5 & 22.7 & 29.3 \\
\hline \hline
\end{tabular}

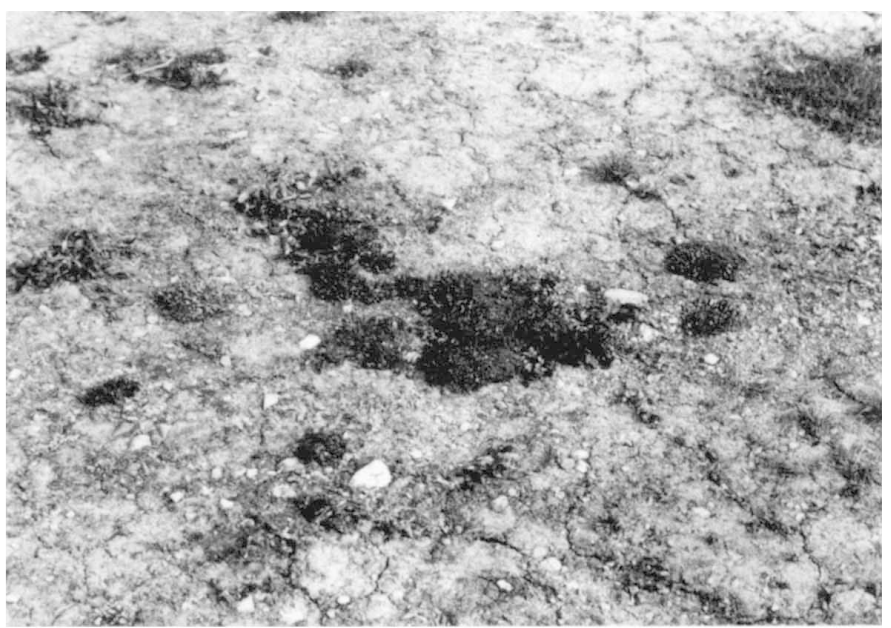

FIG. 4. Cushions of Silene acaulis showing the process of recolonization on the airstrip (14 August 1991).

the Pass. The more exposed and well-drained moraines have only a few scattered plants, for example Poa glauca, Carex nardina, Potentilla hookeriana, and Saxifraga oppositifolia, whereas areas with a prolonged snow cover are characterized by Ranunculus pygmaeus, Minuartia biflora, Erigeron humilis, Taraxacum arcticum, and Melandrium apetalum. There are a few sheltered herb slopes with low arctic species such as Botrychium lunaria, Thalictrum alpinum, Sibbaldia procumbens, Gentiana tenella, and Taraxacum brachyceras. Fens with Eriophorum triste, E. scheuchzeri, E. callitrix, Arctagrostis latifolia, Carex bigelowii, and C. saxatilis follow the small rivers and cover wet depressions.

The vegetation line is reached at $1430 \mathrm{~m}$ north of the Pingo Pass and lies much lower than in the continental parts of Staunings Alper, where a few observations from levels above $2000 \mathrm{~m}$ have been made.

\section{FIELD WORK 1991}

My wife and I spent nearly one month during the summer 1991 in the region of the Pingo Pass (20 July to 18 August). From our base camp near the airstrip, we explored the area by making one-day excursions in all directions, studying the vegetation and the altitudinal distribution of vascular plants between $210 \mathrm{~m}$ (Schuchert Dal) and the summits of the mountains north $(1680 \mathrm{~m})$ and south $(1150 \mathrm{~m})$ of the Pass.

The vegetation of the airstrip (Locality A) was examined several times during the summer to find as many species as possible. On 15 August, four additional sites were studied along the dirt road to the south $(\mathrm{B}, \mathrm{C}$ and $\mathrm{D})$ and to the east (E). Details of the five study sites (A-E) are given in the footnotes of Table 2. These sites are compared with 55 control sites at distances up to ca. $1 \mathrm{~km}$ from the study sites, which represent all types of vegetation found on the plateau west of the Pingo Pass. The plant lists of the 
TABLE2. Distribution of the observed species on the airfield and the dirt roads. The nomenclature and sequence follow Böcher et al. (1978).

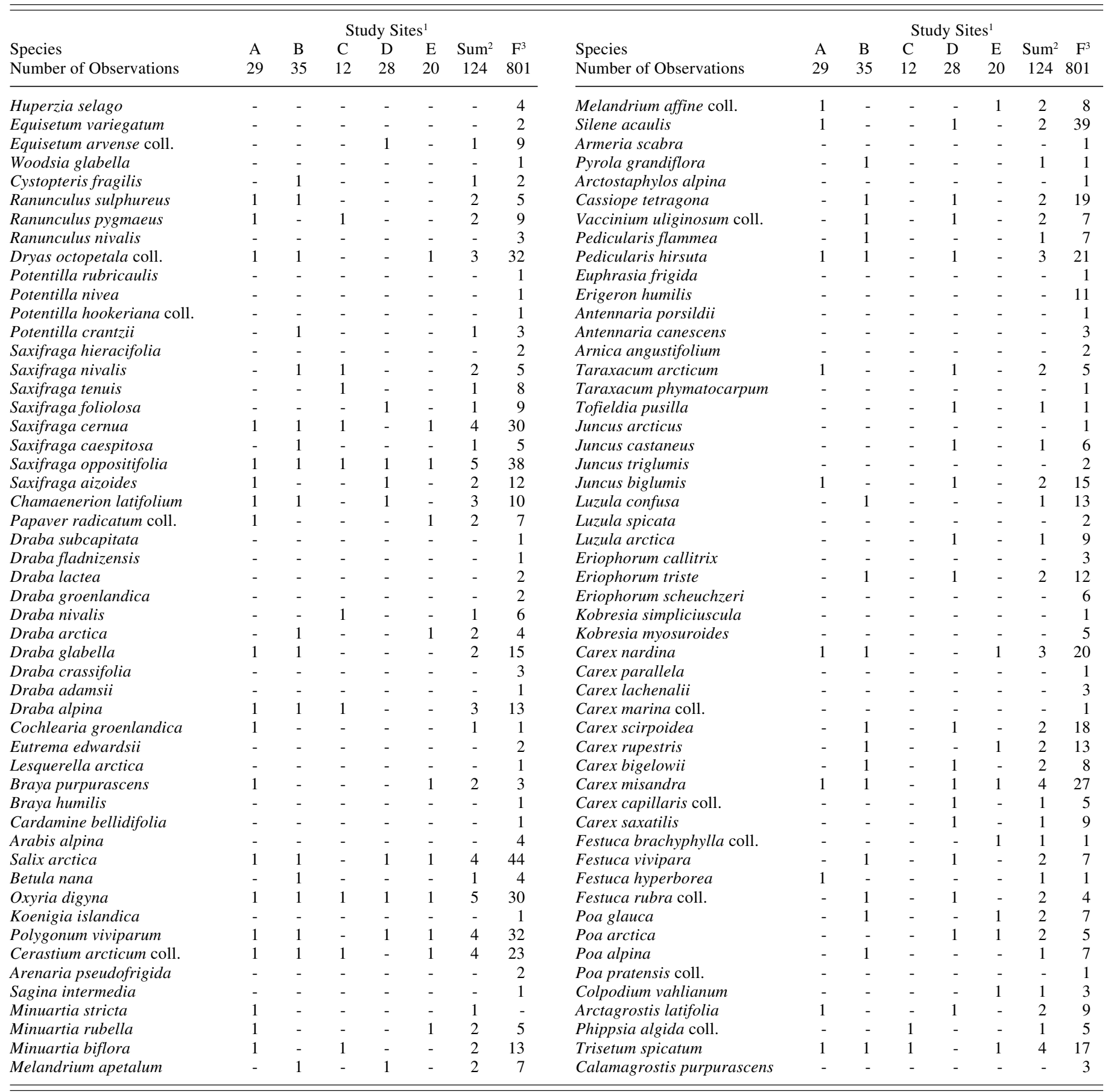

${ }^{1} \mathrm{~A}=$ airstrip, alt. $510 \mathrm{~m} ; \mathrm{B}=$ dirt road ca $1.0 \mathrm{~km}$ south of the airfield, alt. $540 \mathrm{~m} ; \mathrm{C}=$ dirt road ca. $1.5 \mathrm{~km}$ south of the airfield, alt. $550 \mathrm{~m} ; \mathrm{D}=$ dirt road ca. $1.5 \mathrm{~km}$ south of the airfield, alt. $540 \mathrm{~m} ; \mathrm{E}=$ dirt road near the west end of the airfield, alt. $490 \mathrm{~m}$.

${ }^{2}$ Sum $=$ sum of the five study sites A-E.

${ }^{3} \mathrm{~F}=$ sum of the 55 control sites.

control sites include all species of vascular plants found within a circle ca. $10 \mathrm{~m}$ in diameter.

\section{RESULTS}

The five study sites have changed little in general appearance since the airstrip and the dirt roads were constructed, apart from a few minor instances of local stream erosion. Today the vegetation of the airstrip has reached a cover of approximately two to five percent (Fig. 4). We recorded 62 species at the study sites. Plant lists from the five study sites are presented in Table 2. The nomenclature and sequence follow Böcher et al. (1978). 
TABLE 3. The five families best represented in the study sites.

\begin{tabular}{lccc}
\hline \hline Family & $\begin{array}{c}\text { Study sites } \\
(\mathrm{M})\end{array}$ & $\begin{array}{c}\text { Control sites } \\
(\mathrm{N})\end{array}$ & $\begin{array}{c}\text { Percentage } \\
(\mathrm{M} / \mathrm{N})\end{array}$ \\
\hline Caryophyllaceae & 8 & 9 & $89 \%$ \\
Poaceae & 11 & 13 & $85 \%$ \\
Saxifragaceae & 7 & 9 & $78 \%$ \\
Juncaceae & 4 & 7 & $57 \%$ \\
Cyperaceae & 8 & 18 & $44 \%$ \\
\hline \hline
\end{tabular}

\section{DISCUSSION}

The number of 62 species on the airstrip and on the dirt roads is surprisingly high, representing $49 \%$ of the 126 recorded species of the total area studied in summer 1991 and $60 \%$ of the 103 species found at the 55 control sites that we examined in detail.

Of the five study sites, B has the greatest number of species: 35 . Snow-patch plants occur, because melting water from a snow-fan passes the dirt road. A small carpet of Betula-heath grows in a sheltered niche below the road.

The airstrip and sites D and $\mathrm{E}$ have similar numbers of species $(29,28$, and 20). Species from dry habitats are well represented. Site $\mathrm{C}$ is a late-melting snow patch with only 12 species.

The only three species occurring in five or more of the control sites but not represented at the study sites were Erigeron humilis, Eriophorum scheuchzeri and Kobresia myosuroides. Conversely, of the 46 species present at one to three of the control sites, only eight occurred at the study sites. Common species seem to be the most successful colonists. Surprisingly, one species, Minuartia stricta, was found on the airstrip although it was absent from the control sites.

When the number of species in each family occurring in the study sites is expressed as a percentage of the total number occurring on the Pass, five families have values above $40 \%$ (Table 3 ).

It may be important that these families have particularly small seeds or are known to be bird-dispersed. More significantly, berry- or bulbil-producing species, which are probably bird-dispersed, are well represented on the study sites. All the important heath species were observed too, although no Salix arctica more than eight years old was found. Not surprisingly, species typical of herb slopes and snow patches were absent or only poorly represented. No species of Asteraceae were found on the study sites.

Typically, colonization occurs in two stages: first, the establishment of pioneer species; and subsequently, the establishment of offspring around these plants-either by generative or by vegetative reproduction (Fig. 4). This pattern is best seen in species with rather large seeds and therefore lesssuited for long distance dispersal (e.g., Silene acaulis, Braya purpurascens, Draba alpina, and Cerastium arcticum), or with bulbils (e.g., Saxifraga cernua, Polygonum viviparum, and Festuca vivipara). Such colonization will be most effective in species which quickly reach maturity.
The following local factors seem to have favoured the recolonization:

- The ecological conditions of the airstrip and the dirt roads are similar to the dry and windswept terraces which are well represented in the area (Figs. 3 and 4).

- The study sites are situated towards the lower end of the plateau, which favours the accumulation of snow, detritus, seeds, and bulbils by wind and meltwater. Many seedlings grow in niches at the edges of the airstrip, where small snow patches offer good conditions for the germination of seeds and bulbils.

- The strong and turbulent winds transport sand, finegrained material of the organic crust, and plant particles all over the Pass, and these accumulate at sheltered places. These micro-habitats offer good conditions for the development of plants.

- Many seed- and bulbil-eating birds are frequent in the Pass. Snow buntings have been seen to eat bulbils of Saxifraga cernua and Polygonum viviparum.

- Groups of musk-oxen often graze and rest on the airstrip, so manuring the ground and transporting material sticking to their hooves and wool. A side effect might be that the re-established plants are destroyed by grazing or trampling of musk-oxen (Fig. 3).

It is difficult to draw any conclusions regarding longdistance dispersal. As stated above, Minuartia stricta was found at only one of the study sites, but this rather inconspicuous species might possibly have been overlooked elsewhere.

The successful revegetation might be explained partially by the rather high water-saturating capacity of the soil. Elsewhere on the plateau the recolonization of a disturbed surface has not been as successful: near the lake Loms $\varnothing$, the wheel marks are still clearly visible where a vehicle passed through the delta of a meltwater river some 35 years ago. The vegetation has still not recovered.

Our limited field work in 1991 did not reveal how the individual species have succeeded in building up and maintaining a new population on the disturbed surface of the airfield and the two dirt roads. As shown in the literature (e.g., Barrett and Schulten, 1975; Bell and Bliss, 1980; Bliss and Grulke, 1988) vascular plants use different strategies to establish long-term populations under High Arctic conditions. The dynamics of revegetation of a disturbed surface can be understood only when the whole cycle of production, dispersal, viability, survival, and germination of propagules is known for the individual species, and when the processes of competition, selection, and succession have been analyzed.

We recommend a follow-up study of the revegetation of the airstrip and of the dirt roads near the Pingo Pass. Such a study should focus on two questions of interest. 1) Which species first recolonized the airstrip from propagules 
surviving the disturbance of the soil? 2) Which species has the disturbance of the surface favoured, e.g., by providing a better chance for germination, or removing competitors?

\section{ACKNOWLEDGEMENTS}

Dr G. Halliday (Lancaster University, U.K.) reviewed the manuscript for linguistic accuracy. Dr. B. Fredskild and C. Bay (Greenland Herbarium of the Botanical Museum, Copenhagen) identified the herbarium specimens and contributed valuable comments. B. Strandberg (Copenhagen) supplemented the list of literature. The National Survey and Cadastre, Denmark courteously made available a copy of an unpublished map (1:50 000) and aerial photos (1:150 000) of the working area.

\section{REFERENCES}

ANONYMOUS. 1989. Klima. Jameson Land. Del 1. Tekst of tabeller. Nuna Tek. Sektionen for Hydrotekniske Unders $\emptyset$ gelser, DK-2100 Copenhagen.

BARRETT, P., and SCHULTEN, R. 1975. Disturbance and the successional response of arctic plants on polar desert habitats. Arctic 28:70-73.

BAY, C. 1992. A phytogeographical study of the vascular plants of northern Greenland-north of $74^{\circ}$ northern latitude. Meddelelser om Grønland, Bioscience 36. 102 p.

BAY, C., and HOLT, S. 1986. Vegetationskortlaegning af Jameson Land 1982-86. København: Grønlands Fiskeri- og Miljøundersøgelser and Grønlands Botaniske Undersøgelser.

BELL, K.L., and BLISS, L.C. 1980. Plant reproduction in a High Arctic environment. Arctic and Alpine Research 12:1-10.

BLISS, L.C., and GRULKE, N.E. 1988. Revegetation in the High Arctic: Its role in reclamation of surface disturbance. In: Kershaw, P., ed. Northern environmental disturbances. Boreal Institute of Northern Studies, University of Alberta, Edmonton, Occasional Publication 14:43-55.

BÖCHER, T., FREDSKILD, B., HOLMEN, K., and JAKOBSEN, K. 1978. Grønlands flora. 3rd ed. København: P. Haase and Søns Forlag.

FREDSKILD, B. 1990. Grønlands Botaniske Undersøgelse 1989 [Greenland Botanical Survey 1989]. København: Botanisk Museum.
FREDSKILD, B., BAY, C., and HOLT, S. 1982. Botaniske Undersøgelse pa Jameson Land 1982. København: Grønlands Botaniske Undersøgelse, Botanisk Museum.

FREDSKILD, B., BAY, C., HOLT, S., and NIELSEN, B. 1986. Grønlands Botaniske Undersøgelse 1985. København: Botanisk Museum.

GELTING, P. 1934. Studies on the vascular plants of East Greenland between Franz Joseph Fjord and Dove Bay (Lat. $73^{\circ} 15^{\prime}-76^{\circ} 20^{\prime}$ N.). Meddelelser om Grønland 101(2). 340 p.

HALLIDAY, G. 1981. British North-east Greenland Expedition 1980: 20-28. Lancaster: University of Lancaster.

HENRIKSEN, N. 1986. Geological map of Greenland 1:500 000. Scoresby Sund. Sheet 12. København: Grønlands Geologiske Undersøgelse.

HENRIKSEN, N., PERCH-NIELSEN, K., and ANDERSEN, C. 1980. Geological map of Greenland 1:100 000. Sydlige Stauning Alper $71 \varnothing .2$ Nord. The regional geology of a segment of the Caledonian fold belt, and adjacent post-Caledonian rocks, Scoresby Sund region, East Greenland. København: Grønlands Geologiske Undersøgelse.

HOLT, S. 1984. Sneunders øgelser i relation til vegetation, Jameson Land 1984 København: Grønlands Fiskeri- og Miljøundersøgelser.

MÜLLER, F. 1959. Beobachtungen über Pingos. Detailuntersuchungen in Ostgrönland und in der kanadischen Arktis. Meddelelser om Grønland 153(3). 127 p.

OHMURA, A., and REEH, N. 1991. New precipitation and accumulation maps for Greenland. Journal of Glaciology 37(125):140-148.

SCHWARZENBACH, F.H. 1960. Die arktische Steppe in den Trockengebieten Ost- und Nordgrönlands. Bericht des Geobotanischen Institutes der ETH Zürich, Stiftung Rübel.31.Heft 1959:41-64.

. 1961. Botanische Beobachtungen in der Nunatakkerzone Ostgrönlands zwischen $74^{\circ}$ und $75^{\circ} \mathrm{n} . \mathrm{Br}$. Meddelelser om Grønland 163(5). 172 p.

SEIDENFADEN, G., and SØRENSEN, T. 1937. The vascular plants of North-east Greenland from $74^{\circ} 30^{\prime}$ to $79^{\circ} 00^{\prime}$ N.Lat. and a summary of all species found in East Greenland. Meddelelser om Grønland 101(4). 215 p.

SØRENSEN, T. 1933. The vascular plants of East Greenland from $71^{\circ} 00^{\prime}$ to $73^{\circ} 30^{\prime}$ N.Lat. Meddelelser om Grønland 101(3). 177 p. 